\title{
Effects of Dietary Garlic (Allium sativum Linn.) Supplementation on Body Weight and Gut Morphometry of Commercial Broilers
}

\author{
Efectos de la Suplementación Dietética de Ajo (Allium sativum Linn.) sobre el Peso \\ Corporal y la Morfometría Intestinal de los Pollos de Engorde Comercial \\ "Oladele, O. A.; "*'Emikpe, B. O. \& "Bakare, H.
}

OLADELE, O. A.; EMIKPE, B. O. \& BAKARE, H. Effects of dietary garlic (Allium sativum Linn.) supplementation on body weight and gut morphometry of commercial broilers. Int. J. Morphol., 30(1):238-240, 2012.

SUMMARY: The effect of garlic on the absorptive surface of the small intestine of broilers was investigated towards elucidating its mechanism of growth promotion. One hundred day-old Arbor acre broilers were reared in 4 separate groups of twenty-five each. Broiler diet was supplemented with graded doses of garlic meal viz: 0\% - group A; $0.125 \%$ - group B; $0.25 \%$ - group C; $0.5 \%$ - group D. Feed conversion ratio (FCR) was determined at 6 week-old. At 8 week-old, five broilers/group were selected randomly, euthanized and sections of the jejunum were harvested for histological examination. Villi lengths, widths and cryptal depths were determined. Mean body weight at 8 weeks old was highest in group B $(1930 \pm 41 \mathrm{~g})$ and least in group A $(1850 \pm 92 \mathrm{~g})$. FCR was highest in group D (4.34) and least in group B (3.8). Mean villi length, villi width and cryptal depth were highest ( $\mathrm{p}<0.05)$ in group B i.e. $39.3 \pm 2.3 \mathrm{~mm}, 7.64 \pm 1.6$ $\mathrm{mm}$ and $23.0 \pm 1.6 \mathrm{~mm}$, respectively, indicating increased absorptive surface area. It was concluded that garlic meal supplementation at $0.125 \%$ in the diet of commercial broilers improved body weight gain and FCR by increasing villi length, villi width and cryptal depth.

KEY WORDS: Body weight; Broilers; Garlic; Gut morphometry.

\section{INTRODUCTION}

Voluntary reduction in the use of antibiotic growth promoters has compelled producers to search for alternatives. Non-conventional growth promoters are utilized in broiler nutrition to improve nutrient digestibility, control pathogenic microorganisms, facilitate favourable intestinal balance and enhance absorption of calorigenic nutrients across the gut wall by increasing its absorptive capacity (Al-Harthi, 2001; El-Deek et al., 2002).

Garlic (Allium sativum), is a well known spice and herbal medicine for the prevention and treatment of a variety of diseases (Adimoradi et al., 2006). It has been shown to exhibit antimicrobial, antioxidant, and anti-hypertensive properties (Konjufca et al., 1997; Sivam, 2001). As a natural feed additive, garlic has been reported to improve broiler growth, feed conversion ratio and decreased mortality (Jagdish \& Pandey, 1994; Tollba \& Hassan, 2003).

The mechanism of action of garlic as a growth promoter is yet to be fully elucidated. It was considered that garlic might have the ability to improve absorptive capacity of the small intestine via structural alterations. This study was therefore carried out to investigate the effect of garlic on the structure of the intestinal mucosa of commercial broilers.

\section{MATERIAL AND METHOD}

Experimental Chickens and Maintenance. One hundred day-old broilers of the Arbor acres breed were purchased from a commercial hatchery in Ibadan, Nigeria. They were randomly selected into 4 separate treatment groups (A, B, C and D) of twenty-five each and reared in different cages (open sided) for 8 weeks. The chicks were fed ad libitum with broiler starter ration (from day-old to 4 week-old) and broiler finisher ration (from 5-8 weeks-old) supplemented with varying levels of garlic meal. The broilers were administered multivitamins in drinking water from day 1 to 5 of age and

\footnotetext{
* Departments of Veterinary Medicine, University of Ibadan, Ibadan, Nigeria. ** Departments of Veterinary Pathology, University of Ibadan, Ibadan, Nigeria.
} 
Enrofloxacin $^{\mathrm{R}}$ prophylactically from day 9 to day 13 of age. They were also administered Newcastle disease (ND) vaccine, HB1 strain on day $1, \mathrm{ND}$ vaccine, LaSota strain on day 21 and infectious bursal disease (IBD) vaccine on days 9 and 18 of age. The care and handling of these chickens complied with guidelines of the University of Ibadan.

Experimental Procedure. The garlic meal used for this study consisted of $70 \%$ dried garlic powder and $30 \%$ wheat offal as carrier (Javandel et al., 2008). Feed for group A was not supplemented with garlic and served as the control group. Group B had $0.125 \%$ garlic meal in feed i.e. $1.25 \mathrm{~g} / \mathrm{kg}$ feed. Group C had $0.25 \%$ garlic meal i.e. $2.5 \mathrm{~g} / \mathrm{kg}$ feed and Group $\mathrm{D}$ had $0.5 \%$ garlic meal i.e. $5 \mathrm{~g} / \mathrm{kg}$ feed.

Feed intake and body weights of ten randomly selected birds in each group were measured weekly and weight gains as well as feed conversion ratio were calculated. At 8 week-old, five broilers per group were selected randomly and euthanized in $\mathrm{CO}_{2}$ chamber. Sections of the jejunum were harvested and fixed in $10 \%$ formalin. Histological sections were cut and stained with Haematoxylin \& Eosin stain. From each section, five randomly selected villi were measured in each slide per field and five fields were used. Villi lengths, widths and cryptal depths were measured in microns under the microscope using a graduated eyepiece with a x10 objective lens (Eyarefe $e t$ al., 2008).

Mean values between groups were compared for significant difference using Duncan's multiple range test while mean body weights between groups were compared using the Least significant difference (LSD) method of multiple comparisons.

\section{RESULTS}

Mean body weights of $1850 \pm 92 \mathrm{~g}, 1930 \pm 41 \mathrm{~g}$, $1890 \pm 63 \mathrm{~g}$ and $1890 \pm 110 \mathrm{~g}$ were obtained for groups $\mathrm{A}$, $\mathrm{B}, \mathrm{C}$ and D respectively at 8 weeks of age. Feed conversion ratio was highest in group D i.e 4.34 and least in group B i.e. 3.8 (Table I).

Mean values for villi length and width as well as cryptal depths for the different groups of broilers at 8 weeks of age are presented in Table II. While group B had the highest mean villi length and width of $39.3 \pm 2.3 \mathrm{~mm}$ and $7.64 \pm 1.7 \mathrm{~mm}$ respectively, group $\mathrm{C}$ had the least villi length of $25.6 \pm 2.0 \mathrm{~mm}$ and group A had the least villi width of $5.76 \pm 1.1 \mathrm{~mm}$. Cryptal depth was also highest in group B $(23.0 \pm 1.6 \mathrm{~mm})$.
Table I. Feed intake, body weight gain and feed conversion ratio of broiler on garlic meal supplement during total rearing phase (1-6 weeks of age).

\begin{tabular}{lccc}
\hline Group & $\begin{array}{c}\text { Feed intake } \\
\text { (g/bird/day) }\end{array}$ & $\begin{array}{c}\text { Body weight } \\
\text { gain (g/bird/day) }\end{array}$ & $\begin{array}{c}\text { Feed } \\
\text { conversion } \\
\text { ratio }\end{array}$ \\
\hline A & 99.44 & 23.87 & 4.17 \\
B & 100.61 & 26.49 & 3.80 \\
C & 100.86 & 24.35 & 4.14 \\
D & 104.71 & 24.11 & 4.34 \\
\hline
\end{tabular}

Table II. Mean villi lengths, villi widths and cryptal depths of commercial broiler on garlic meal supplementation. Figures with different superscript within the same column are significantly different $(\mathrm{p}<0.05)$.

\begin{tabular}{lccc}
\hline Group & Length & Width & Cryptal Depth \\
\hline A & $27.8 \pm 2.9^{\mathrm{b}}$ & $5.76 \pm 1.1 \mathrm{~b}$ & $21.3 \pm 2.1^{\mathrm{a}}$ \\
B & $39.3 \pm 2.3^{\mathrm{a}}$ & $7.64 \pm 1.6 \mathrm{a}$ & $23.0 \pm 1.6^{\mathrm{a}}$ \\
C & $25.6 \pm 2.0^{\mathrm{c}}$ & $6.02 \pm 1.1^{\mathrm{b}}$ & $11.1 \pm 1.1^{\mathrm{c}}$ \\
D & $27.4 \pm 1.8^{\mathrm{b}}$ & $7.6 \pm 1.5 \mathrm{a}$ & $13.7 \pm 4.3^{\mathrm{b}}$ \\
\hline
\end{tabular}

\section{DISCUSSION}

This study showed that feed intake was higher in garlic supplemented broilers i.e. groups B, C and D than in control group $\mathrm{A}$ and the increase was dose-dependent. However, body weight gain was highest in group B i.e. $26.49 \mathrm{~g} / \mathrm{b} / \mathrm{d}$ which also had the least feed conversion ratio of 3.8. In an earlier study by Ghosh et al. (2011), significant increase $(\mathrm{p}<0.01)$ in feed intake and body weight gain was reported in pre-ruminant stage calves fed with diet supplemented with garlic compared with control group. Also, Jagdish \& Pandey as well as Tollba \& Hassan reported improved growth and feed conversion ratios in chickens fed garlic supplemented diets. Thus, the results of the present study is in concurrence with these earlier reports, furthermore it has shown that $0.125 \%$ garlic meal supplementation in the diet of these commercial broilers resulted in more efficient production. While Jagdish \& Pandey reported lower feed conversion ratio in cocks fed $0.25 \%$ garlic meal than in those fed $0.5 \%$ garlic meal, the present study has shown a further reduction in FCR at $0.125 \%$ garlic meal supplementation.

Assessement of the morphometry of the jejunum showed that values of mean villi length and width were significantly higher $(\mathrm{p}<0.05)$ in group B than in the other 3 groups. This represents an increase in the absorptive surface area of the intestine and thus an increased absorptive capacity with the resultant highest body weight gain and lowest FCR in this group. Also, the value of mean cryptal depth in group 
B was significantly higher $(\mathrm{p}<0.05)$ than in the other 3 groups. Since crypt cells are responsible for secretion of electrolytes which enhance water secretion into the intestinal lumen for the purpose of digestion (Bowen, 2011), it could be inferred that digestibility was enhanced in group B. Stem cells at the base of crypts is known to be the source of all cells lining the crypt and the villi (Bowen). Thus, a higher cryptal depth observed in group B is an indication of a higher mucosal proliferation activity (Zhou et al., 2003) for more efficient digestibility and absorption of ingested feed in this group. This study has shown that garlic has the ability to increase the digestive and absorptive capacity of the small intestine of commercial broilers by increasing the cryptal depth as well as the absorptive surface area of the intestine i.e. villi length and width. It was therefore concluded that garlic meal supplementation at $0.125 \%$ in the diet of commercial broilers improved body weight gain and FCR by increasing villi length, villi width and cryptal depth.

OLADELE, O. A.; EMIKPE, B. O. \& BAKARE, H. Efectos de la suplementación dietética de ajo (Allium sativum Linn.) sobre el peso corporal y la morfometría intestinal de los pollos de engorde comercial. Int. J. Morphol., 30(1):238-240, 2012.

RESUMEN: Fue investigado el efecto del ajo sobre la superficie de absorción del intestino delgado de pollos de engorde para dilucidar su mecanismo de promoción del crecimiento. Cien pollos pollos de engorde Arbor acres de cien días de edad fueron criados en 4 grupos. La dieta de los pollos se complementó con dosis graduales de ajo en: $0 \%$ - el grupo A; 0,125\% - el grupo B, 0,25\% - el grupo C y $0,5 \%$ - el grupo de alimentación D. El índice de conversión alimenticia (ICA) se determinó a las 6 semanas de edad. A las 8 semanas de edad, 5 pollos de cada grupo fueron seleccionados al azar, se eutanizaron y secciones del yeyuno fueron preparadas para el examen histológico. Fueron determinadas la longitud y el ancho de las vellosidades, junto a la profundidad de las criptas. La media de peso corporal a las 8 semanas fue mayor en el grupo B $(1930 \pm 41 \mathrm{~g})$ y menor en el grupo A $(1850 \pm 92 \mathrm{~g})$. El ICA fue mayor en el grupo D $(4,34)$ y menor en el grupo B $(3,8)$. La media de longitud de las vellosidades, ancho de las vellosidades y profundidad de las criptas fueron mayores ( $\mathrm{p}<0,05)$ en el grupo B es decir, 39,3 $\pm 2,3 \mathrm{~mm}, 7,64 \pm$ $1,6 \mathrm{~mm}$ y 23,0 $\pm 1,6 \mathrm{~mm}$, respectivamente, indicando mayor área de superficie de absorción. Se concluyó que los suplementos de ajo en concentración del $0,125 \%$ en la dieta de los pollos de engorde comerciales mejoró la ganancia de peso corporal y el ICA mediante el aumento de longitud y ancho de las vellosidades, junto a la profundidad de las criptas.

\section{PALABRAS CLAVE: Peso corporal; Pollos; Ajo; Morfometría intestinal.}

\section{REFERENCES}

Adibmoradi, M.; Navidshad, B.; Saif, D. J. \& Royan, M. Effect of dietary garlic meal on histological structure of small intestine in broiler chickens. J. Poult. Sci., 43:378-83, 2006.

Al-Harthi, M. A. Efficacy of vegetable diets with antibiotics and different types of spices or their mixtures on performance, economic efficiency and carcass traits of broilers. J. Agric. Sci., Mansoura Univ., 27:901-13, 2001.

Bowen, R. Villi, crypts and the life cycle of small intestinal enterocytes, 2011. Available in: http://www.vivo.colostate.edu/hbooks/pathphys/ digestion/smallgut/lifecycle.html.

El-Deek, A.A.; Attia, Y. A. \& Hannfy, M. M. Effect of anise (Pimpinella anisum), ginger (Zingiber officinale roscoe) and fennel (Foeniculum vulgare) and their mixture on performance of broilers. Arch. Geflügelk., 67(2):92-6, 2002,

Eyarefe, O. D.; Emikpe, B. O. \& Arowolo, F. O. Small bowel responses to enteral and glutamine administration following massive small bowel resection in rabbit. Afr. J. Med. Med. Sci., 37:309-14, 2008.

Ghosh, S.; Mehla, R. K.; Sirohi, S. K. \& Tomar, S. K. Performance of crossbred calves with dietary supplementation of garlic extract. $J$. Anim. Physiol. Anim. Nutr., 95:449-55, 2011.

Jagdish, P. \& Pandey, R.C. Effect of different levels of garlic inclusion in the ration of cockerels in their growth rate and feed conversion ratio. Poul. Adv., 27:39-41, 1994.
Javandel, F.; Navidshad, B.; Seifdavati, J.; Pourrahimi, G. H. \& Baniyaghoubi, S. The Favorite Dosage of Garlic Meal as a Feed Additive in Broiler Chickens Ratios. Pakistan J. Biol. Sci., 11:17469, 2008 .

Konjufca, V. H.; Pesti, G. M. \& Bakalli, R. I. Modulation of cholesterol levels in broiler meat by dietary garlic and copper. Poult. Sci., 76:1264-71, 1997.

Sivam, G. P. Protection against Helicobacter pylori and other bacterial infections garlic. J. Nutr, 131:1106S-8S, 2001.

Tollba, A. A. H. \& Hassan, M. S. H. Using some natural additives to improve physiological and productive performance of broiler chicks under high temperature conditions 2- black cumin (Nigella Sativa) or garlic (Allium sativum) Egypt. Poult. Sci. 23:327-40, 2003.

Zhou, X.; Li, N. \& Li, J. S. Growth hormone stimulates remnant small bowel epithelial cell proliferation. World J. Gastroenterol., 6:90913, 2003.

Correspondence to:

Dr. Omolade A. Oladele

Departments of 1 Veterinary Medicine

University of Ibadan

Ibadan

NIGERIA

Email: Lade_ed@yahoo.co.uk lade.oladele@gmail.com Received: 30-07-2011

Accepted: 29-08-2011 